


ISSN: 0973-4945; CODEN ECJHAO

http://www.e-journals.net

E-Journal of Chemistry 2009, 6(2), 315-322

\title{
Studies on Dyeing Performance of Novel Acid Azo Dyes and Mordent Acid Azo Dyes Based on 2,4-Dihydroxybenzophenone
}

\author{
BHARAT C. DIXIT*, HITENDRA M. PATEL, \\ DHIRUBHAI J. DESAI and RITU B. DIXIT" \\ Department of Chemistry, V. P. \& R. P. T. P. Science College, \\ Vallabh Vidyanagar-388120, Gujarat, India. \\ \#Ashok \& Rita Patel Institute of Integrated study in Biotechnology \& \\ Allied Science, New Vallabh Vidyanagar-388120, Gujarat, India. \\ dixits20002003@yahoo.co.in
}

Received 10 August 2008; Accepted 5 October 2008

\begin{abstract}
Novel acid azo and mordent acid azo dyes have been prepared by the coupling of diazo solution of different aminonaphthol sulphonic acids and aromatic amino acids with 2,4-dihydroxybenzophenone. The resultant dyes were characterized by elemental analysis as well as IR and ${ }^{1} \mathrm{H}$ NMR spectral studies. The UV-visible spectral data have also been discussed in terms of structure property relationship. The dyeing assessments of all the dyes were evaluated on wool and silk textile fibers. The dyeing of chrome pretreated wool and silk have also been monitored. The result shows that better hue was obtained on mordented fiber. Results of bactericidal studies of chrome pretreated fibers revealed that the toxicity of mordented dyes against bacteria is fairly good. Dyeing on wool and silk fibers resulted in yellowish pink to reddish brown colourations having excellent light fastness and washing fastness.
\end{abstract}

Keywords: Acid azo dyes, Chrome dyes, Light fastness, Washing fastness.

\section{Introduction}

Whilst phenols are well established intermediates for the synthesis of various commercial dyes $^{1-6}$, they are marketed in the form of azo disperse, azo-acid dyes etc. All of these dyes having phenolic motif, containing hydroxyl group as an auxochrome group. Such auxochromic $(-\mathrm{OH})$ and chromophoric $(\mathrm{C}=\mathrm{O})$ group containing compound i.e. 2, 4dihydroxybenzophenone has shown wide applications as a polymer additives ${ }^{7-9}$. It is an excellent UV absorber, which prevents the photo degradability of most of vinyl polymers ${ }^{10-12}$. 
The area in which the acid azo dyes and mordent azo dyes formation based on this compound has not been developed except of few patents ${ }^{13-16}$.

The formation of dyes based on this compound may yield the dyes with good hue properties. Hence, in continuation of our earlier work $^{17}$, it was thought interesting to explore the field of acid azo dyes based on 2,4-dihydroxybenzophenone. Thus, the present communication comprises the synthesis, characterizations and dyeing performance of novel acid azo and mordent acid azo dyes based on 2,4-dihydroxybenzophenone.

\section{Experimental}

All the chemicals used were of analytical grade and were further purified as and when required. The aminonaphthol sulphonic acids and aromatic amino acids listed in Scheme 1 were used for diazotization. Wool and silk fibers were gifted by Color Tax (Pvt) Ltd, Surat. Melting points were determined by open capillary method and are uncorrected. The visible absorption spectra were measured on a Carl Zeiss UV/VIS Specord spectrometer, and elemental analysis was carried out on Perkin Elmer CHNS/O Analyzer 2400 Series II. Infrared spectra were recorded in $\mathrm{KBr}$ pellets on a Perkin-Elmer Spectrum GX FT-IR model, proton NMR spectra were recorded on Hitachi R-1500 in DMSO-D 6 solvent and TLC (Thin layer chromatography) was run on a aluminum sheets precoated with silica gel $60 \mathrm{~F}_{245}$, (Merck, Germany) using methanol-water-acetic acid (12:3:7) solvent system. Colour spot was visualized by UV chamber. HTHP dyeing machine (model-LL) was used for dying purpose.

\begin{tabular}{|c|c|c|}
\hline minonaphthole sulphonic acids / & $\mathrm{NaNO}_{2}, \mathrm{HCl}$ & \\
\hline & $0-5$ & $1(a-g)$ \\
\hline
\end{tabular}



Scheme 1 . Synthesis of 2,4-dihydroxybenzophenone based dyes $\left(D_{1}-D_{7}\right)$

Aminonaphthole sulphonic acids and Aromatic amino acids 1(a-g)are as under:<smiles></smiles>

(a) $\mathrm{H}$-acid

(b) J-acid

(c) K-acid

(d) Broners-acid<smiles>Nc1ccc2ccccc2c1S(=O)(=O)O</smiles>

(e) Tobias-acid<smiles>Nc1ccccc1C(=O)O</smiles>

(f) Anthranilic-acid<smiles>Nc1ccc(S(=O)(=O)O)cc1</smiles>

(g) Sulphanilic-acid. 


\section{Synthesis of acid azo dyes}

\section{Diazotization}

Diazotization of various aminonaphthol sulphonic acid and aromatic amino acid 1(a-g) (Scheme 1) was carried out by the method reported in literature ${ }^{18,19}$.

Accordingly each of the aminonaphthol sulphonic acids and aromatic amino acids 1 (a-g) $\left(3.19 \times 10^{-3} \mathrm{~kg}, 0.01 \mathrm{~mol}\right)$ was mixed with $\mathrm{HCl}\left(2.5 \times 10^{-5} \mathrm{~m}^{3}, 37 \%\right)$ in a mortar, transferred to a 3-neck round bottom flask, and additional $\mathrm{HCl}\left(2.0 \times 10^{-5} \mathrm{~m}^{3,} 37 \%\right)$ was added. To the resultant suspension, crushed ice $\left(25 \times 10^{-3} \mathrm{~kg}\right)$ and $\mathrm{NaNO}_{2}\left(2.5 \times 10^{-5} \mathrm{~m}^{3}, 4 \mathrm{~N}\right)$ were added. Diazotization was carried out over $0.5 \mathrm{~h}$ at $5{ }^{0} \mathrm{C}$ with constant stirring.

\section{Coupling procedure}

The coupling of above mentioned diazotized aminonaphthol sulphonic acid and aromatic amino acid 1(a-g) was carried out in the similar manner. The general procedure followed is given below:

2,4-Dihydroxybenzophenone $\left(2.15 \times 10^{-3} \mathrm{~kg}, 0.01 \mathrm{~mol}\right)$ was dissolved in sodium hydroxide $\left(1.2 \times 10^{-5} \mathrm{~m}^{3}, 0.01 \mathrm{~mol}\right)$ solution. The clear solution was cooled in ice-bath and diazonium solution of aminonaphthol sulphonic acid and aromatic amino acid 1 (a-g) was added drop wise over a period of $30 \mathrm{~min}$ with vigorous stirring. The $\mathrm{pH}$ was maintained between 2.0 to 3.0 by simultaneous addition of $10 \% \mathrm{w} / \mathrm{v}$ sodium carbonate solution. Stirring was continued for $2 \mathrm{~h}$, allowing the temperature rise to ambient. The dyes was then filtered off and dissolved in distilled water after that acid azo dyes were obtained by evaporation procedure, and it was dried at room temperature. The dyes were designated as acid azo dye $\left(\mathrm{D}_{1-7}\right)$ and were recrystalised in acetone.

\section{Acid azo dyeing method}

Dyeing of wool and silk fiber, is convenient at $90^{\circ}-130^{\circ} \mathrm{C}$ and at high pressure $(165.6$ $\mathrm{kpa}-207 \mathrm{kpa}$ ) in the laboratory. A model glycerin-bath high-temperature beaker and HTHP (model-LL) dyeing machine was used. For this purpose a paste of finely powdered acid azo dye $\left(6 \times 10^{-5} \mathrm{~kg}\right)$ was prepared with dispersing agent dodamol $(9 \mathrm{x}$ $\left.10^{-5} \mathrm{~kg}\right)$, wetting agent Tween-80 $\left(6 \times 10^{-6} \mathrm{~kg}\right)$ and water $\left(2 \times 10^{-6} \mathrm{~m}^{3}\right)$ in a ball mill. To this paste, water $\left(9.9 \times 10^{-5} \mathrm{~m}^{3}\right)$ was added with stirring and the $\mathrm{pH}$ was adjusted to 2.0 -4.0 using acetic acid, the previously mentioned dye suspension $\left(1 \times 10^{-4} \mathrm{~m}^{3}\right)$ was added to a beaker provided with a lid and a screw cap. Before closing the lid and lightening the metal cap over the beaker a wetted pattern of wool and silk fiber was rolled in to the beaker, and then placed vertically on the rotatory carrier inside the tank and the clamp plate was firmly tightened.

The rotatory carrier was then allowed to rotate in the glycerin-bath and the temperature was raised to $90{ }^{\circ} \mathrm{C}$ at the rate of $2{ }^{\circ} \mathrm{C} / \mathrm{min}$. The dyeing was continued for $1 \mathrm{~h}$ under pressure. After cooling for $1 \mathrm{~h}$, the beaker was removed from the bath and washed with distilled water. The dyed pattern was thoroughly washed with cold water and dried at room temperature.

\section{Mordent dyeing method}

The dye pattern of wool and silk fibers obtained from the above mentioned process was treated with potassium dichromate solution equal to half of the weight of dye and it was allowed to roll into the beaker and again, the beaker was then placed vertically on the rotatory carrier inside the tank and the dyeing was continued for $1 \mathrm{~h}$ under the pressure. After cooling for $1 \mathrm{~h}$, the beaker was removed from the bath and washed with cold distilled water. The dyed pattern was thoroughly washed with warm water and air dried at room temperature. 


\section{Characteristic data of acid azo dyes}

\section{1-[2,4-Dihydroxy-5-(8-hydroxynaphthylazo-3,6-disulphonic acid)phenyl]-1-phenyl-} methanone $\left(D_{1}\right)$

Calculated for $\mathrm{C}_{23} \mathrm{H}_{14} \mathrm{O}_{10} \mathrm{~N}_{2} \mathrm{~S}_{2}$ : M. wt.: $542, \%$ yield: 81 , m. p.: $136-140^{\circ} \mathrm{C}, \mathrm{R}_{\mathrm{f}}$. value: 0.82 ; C, $50.92 \%$; H, $2.58 \%$; N, $5.16 \%$; S, $11.83 \%$. Found: C, $50.88 \%$; H, $2.52 \%$; N, $5.11 \%$; $\mathrm{S}, 11.80 \%$. IR : $3463 \mathrm{~cm}^{-1}(-\mathrm{OH}) ; 3072 \mathrm{~cm}^{-1}$ (=CH, aromatic); $1628 \mathrm{~cm}^{-1}(\mathrm{C}=\mathrm{O}$, diaryl); $1521 \mathrm{~cm}^{-1}(\mathrm{~N}=\mathrm{N}) ; 1520 \mathrm{~cm}^{-1}$ (for naphthalene substitution); $1481 \mathrm{~cm}^{-1}(\mathrm{C}=\mathrm{C}$, aromatic); $1333 \mathrm{~cm}^{-1}$ (C-N); $1101 \mathrm{~cm}^{-1}$ (C-O); $1030 \mathrm{~cm}^{-1}, 650 \mathrm{~cm}^{-1}$ (for sulphonic acid); $732 \mathrm{~cm}^{-1}, 584$ $\mathrm{cm}^{-1}, 481 \mathrm{~cm}^{-1}$ (for substituted benzene). ${ }^{1} \mathrm{H}-\mathrm{NMR}$ : 7.2-7.4 $\delta$ (Ar-H, multiplet), $5.4 \delta$ (Ar$\mathrm{OH}$, singlet), $8.0 \delta\left(-\mathrm{SO}_{3} \mathrm{H}\right.$, singlet, $\left.1 \mathrm{H}\right)$.

\section{1-[2,4-Dihydroxy-5-(4-hydroxynaphthylazo-6-sulphonic acid)phenyl]-1-phenyl- methanone $\left(D_{2}\right)$}

Calculated for $\mathrm{C}_{23} \mathrm{H}_{15} \mathrm{O}_{7} \mathrm{~N}_{2} \mathrm{~S}$ : M. wt.: 463 , \% yield: 78, m. p.: $140-144^{0} \mathrm{C}, \mathrm{R}_{\mathrm{f}}$. value: $0.80 ; \mathrm{C}, 59.61$ $\%$; H, $3.23 \%$; N, $6.04 \%$; S, $6.92 \%$. Found: C, $59.58 \%$; H, $3.19 \%$; N, $6.01 \%$; S, $6.88 \%$. IR : $3450 \mathrm{~cm}^{-1}(-\mathrm{OH}) ; 3082 \mathrm{~cm}^{-1}$ (=CH, aromatic); $1624 \mathrm{~cm}^{-1}\left(\mathrm{C}=\mathrm{O}\right.$, diaryl); $1540 \mathrm{~cm}^{-1}$ (for naphthalene substitution); $1522 \mathrm{~cm}^{-1}(\mathrm{~N}=\mathrm{N}) ; 1490 \mathrm{~cm}^{-1}\left(\mathrm{C}=\mathrm{C}\right.$, aromatic); $1345 \mathrm{~cm}^{-1}(\mathrm{C}-\mathrm{N}) ; 1101 \mathrm{~cm}^{-1}(\mathrm{C}-\mathrm{O})$; $1032 \mathrm{~cm}^{-1}, 653 \mathrm{~cm}^{-1}$ (for sulphonic acid); $744 \mathrm{~cm}^{-1}, 564 \mathrm{~cm}^{-1}, 478 \mathrm{~cm}^{-1}$ (for substituted benzene). ${ }^{1} \mathrm{H}-\mathrm{NMR}$ : 7.2-7.5 $\delta$ (Ar-H, multiplet), $6.3 \delta$ (Ar-OH, singlet), $8.2 \delta\left(-\mathrm{SO}_{3} \mathrm{H}\right.$, singlet, $1 \mathrm{H}$ ).

\section{1-[2,4-Dihydroxy-5-(8-hydroxynaphthylazo-4,6-disulphonic acid)phenyl]-1-phenyl-} methanone $\left(D_{3}\right)$

Calculated for $\mathrm{C}_{23} \mathrm{H}_{14} \mathrm{O}_{10} \mathrm{~N}_{2} \mathrm{~S}_{2}$ : M. wt.: 542 , \% yield: 82, m. p.: 141-146 ${ }^{0} \mathrm{C}, \mathrm{R}_{\mathrm{f}}$. value: $0.85 ; \mathrm{C}, 50.91$ $\%$; H, $2.58 \%$; N, $5.16 \%$; S, $11.83 \%$. Found: C, $50.87 \%$; H, $2.53 \%$; N, $5.10 \%$; S, $11.80 \%$. IR : $3481 \mathrm{~cm}^{-1}(-\mathrm{OH}) ; 3070 \mathrm{~cm}^{-1}$ (=CH, aromatic); $1632 \mathrm{~cm}^{-1}\left(\mathrm{C}=\mathrm{O}\right.$, diaryl); $1542 \mathrm{~cm}^{-1}(\mathrm{~N}=\mathrm{N}) ; 1525 \mathrm{~cm}^{-1}$ (for naphthalene substitution); $1483 \mathrm{~cm}^{-1}\left(\mathrm{C}=\mathrm{C}\right.$, aromatic); $1337 \mathrm{~cm}^{-1}(\mathrm{C}-\mathrm{N}) ; 1103 \mathrm{~cm}^{-1}$ (C-O); 1029 $\mathrm{cm}^{-1}, 650 \mathrm{~cm}^{-1}$ (for sulphonic acid); $737 \mathrm{~cm}^{-1}, 562 \mathrm{~cm}^{-1}, 472 \mathrm{~cm}^{-1}$ (for substituted benzene). ${ }^{1} \mathrm{H}-$ NMR: 7.1-7.3 $\delta$ (Ar-H, multiplet), $5.5 \delta$ (Ar-OH, singlet), $7.9 \delta\left(-\mathrm{SO}_{3} \mathrm{H}\right.$, singlet, $1 \mathrm{H}$ ).

\section{1-[2,4-Dihydroxy-5-(naphthylazo-5-sulphonic acid)phenyl]-1-phenylmethanone $\left(\mathrm{D}_{4}\right)$}

Calculated for $\mathrm{C}_{23} \mathrm{H}_{15} \mathrm{O}_{6} \mathrm{~N}_{2} \mathrm{~S}$ : M. wt.: 447, \% yield: 85, m. p.: $138-142^{0} \mathrm{C}, \mathrm{R}_{\mathrm{f}}$. value: $0.87 ; \mathrm{C}, 61.74$ $\%$; H, $3.35 \%$; N, $6.26 \%$; S, $7.17 \%$. Found: C, $61.70 \%$; H, $3.31 \%$; N, $6.22 \%$; S, $7.14 \%$. IR : $3633 \mathrm{~cm}^{-1}(-\mathrm{OH}) ; 3080 \mathrm{~cm}^{-1}$ (=CH, aromatic); $1652 \mathrm{~cm}^{-1}\left(\mathrm{C}=\mathrm{O}\right.$, diaryl); $1560 \mathrm{~cm}^{-1}$ (for naphthalene substitution); $1532 \mathrm{~cm}^{-1}(\mathrm{~N}=\mathrm{N}) ; 1473 \mathrm{~cm}^{-1} \quad\left(\mathrm{C}=\mathrm{C}\right.$, aromatic); $1338 \mathrm{~cm}^{-1}(\mathrm{C}-\mathrm{N}) ; 1104 \mathrm{~cm}^{-1}(\mathrm{C}-\mathrm{O})$; $1032 \mathrm{~cm}^{-1}, 653 \mathrm{~cm}^{-1}$ (for sulphonic acid); $782 \mathrm{~cm}^{-1}, 741 \mathrm{~cm}^{-1}, 583 \mathrm{~cm}^{-1}, 485 \mathrm{~cm}^{-1}$ (for substituted benzene). ${ }^{1} \mathrm{H}-\mathrm{NMR}$ : 7.2-7.4 $\delta$ (Ar-H, multiplet), $6.10 \delta$ (Ar-OH, singlet), $8.1 \delta\left(-\mathrm{SO}_{3} \mathrm{H}\right.$, singlet, $1 \mathrm{H}$ ).

\section{1-[2,4-Dihydroxy-5-(naphthylazo-8-sulphonic acid)phenyl]-1-phenylmethanone $\left(D_{5}\right)$}

Calculated for $\mathrm{C}_{23} \mathrm{H}_{15} \mathrm{O}_{6} \mathrm{~N}_{2} \mathrm{~S}$ : M. wt.: 447, \% yield: 86, m. p.: 140-144 ${ }^{0} \mathrm{C}, \mathrm{R}_{\mathrm{f}}$. value: 0.86; C, $61.74 \%$; H, $3.35 \%$; N $6.26 \%$; S, $7.17 \%$. Found: C, $61.70 \% ; \mathrm{H}, 3.32 \%$; , $6.23 \%$; S,

$7.13 \%$. IR : $3580 \mathrm{~cm}^{-1}$ (-OH, phenolic); $3070 \mathrm{~cm}^{-1}\left(=\mathrm{CH}\right.$, aromatic); $1621 \mathrm{~cm}^{-1}(\mathrm{C}=\mathrm{O}$, diaryl); $1575 \mathrm{~cm}^{-1}$ (for naphthalene substitution); $1531 \mathrm{~cm}^{-1}(\mathrm{~N}=\mathrm{N}) ; 1482 \mathrm{~cm}^{-1}(\mathrm{C}=\mathrm{C}$, aromatic); $1463 \mathrm{~cm}^{-1}(\mathrm{C}-\mathrm{N}) ; 1338 \mathrm{~cm}^{-1}(\mathrm{C}-\mathrm{O}) ; 1034 \mathrm{~cm}^{-1}, 650 \mathrm{~cm}^{-1}$ (for sulphonic acid); $1103 \mathrm{~cm}^{-1}, 732 \mathrm{~cm}^{-1}, 574 \mathrm{~cm}^{-1}, 473 \mathrm{~cm}^{-1}$ (for substituted benzene). ${ }^{1} \mathrm{H}-\mathrm{NMR}: 7.1-7.5 \delta$ (Ar$\mathrm{H}$, multiplet), $6.3 \delta$ (Ar-OH, singlet), $8.2 \delta\left(-\mathrm{SO}_{3} \mathrm{H}\right.$, singlet, $\left.1 \mathrm{H}\right)$.

\section{1-[2,4-Dihydroxy -5-(phenylazo-2-carboxylic acid)phenyl]-1-phenylmethanone $\left(D_{6}\right)$}

Calculated for $\mathrm{C}_{20} \mathrm{H}_{13} \mathrm{O}_{5} \mathrm{~N}_{2}$ : M. wt.: 361 , \% yield: 80, m. p.: $145-148^{0} \mathrm{C}, \mathrm{R}_{\mathrm{f}}$. value: $0.83 ; \mathrm{C}$, $66.48 \%$; H, $3.60 \%$; N, $7.75 \%$. Found: C, $66.43 \%$; H, $3.58 \%$; N, $7.71 \%$. IR : $3430 \mathrm{~cm}^{-1}$ 
(-OH, phenolic); $3540 \mathrm{~cm}^{-1}$ (-OH, acidic); $3062 \mathrm{~cm}^{-1}$ (=CH, aromatic); $1634 \mathrm{~cm}^{-1}(\mathrm{C}=\mathrm{O}$, diaryl); $1678 \mathrm{~cm}-1(\mathrm{C}=\mathrm{O}$, carboxylic acid $) ; 1581 \mathrm{~cm}^{-1}(\mathrm{~N}=\mathrm{N}) ; 1483 \mathrm{~cm}^{-1}(\mathrm{C}=\mathrm{C}$, aromatic); $1352 \mathrm{~cm}^{-1}(\mathrm{C}-\mathrm{N}) ; 1103 \mathrm{~cm}^{-1}$ (C-O); $1100 \mathrm{~cm}^{-1}, 850 \mathrm{~cm}^{-1}$ (for carboxylic acid); $783 \mathrm{~cm}^{-1}, 741$ $\mathrm{cm}^{-1}, 583 \mathrm{~cm}^{-1}, 482 \mathrm{~cm}^{-1}$ (for substituted benzene). ${ }^{1} \mathrm{H}-\mathrm{NMR}: 7.1-7.5 \delta$ (Ar-H, multiplet), 5.5 $\delta$ (Ar-OH, singlet), $10.9 \delta$ (-COOH, singlet, $1 \mathrm{H})$.

\section{1-[2,4 -Dihydroxy -5-(phenylazo-4-sulphonic acid)phenyl]-1-phenylmethanone $\left(D_{7}\right)$}

Calculated for $\mathrm{C}_{19} \mathrm{H}_{13} \mathrm{O}_{6} \mathrm{~N}_{2} \mathrm{~S}$ : M. wt.: 397 , \% yield: 83, m. p.: $150-154^{0} \mathrm{C}, \mathrm{R}_{\mathrm{f}}$. value: $0.85 ; \mathrm{C}$, $57.43 \%$; H, $3.27 \%$; N, $7.05 \%$; S, $8.07 \%$. Found: C, $57.39 \% ; \mathrm{H}, 3.23 \% ; \mathrm{N}, 7.01 \% ; \mathrm{S}$, $8.04 \%$. IR : $3590 \mathrm{~cm}^{-1}(-\mathrm{OH}) ; 3063 \mathrm{~cm}^{-1}$ (=CH, aromatic); $1632 \mathrm{~cm}^{-1}(\mathrm{C}=\mathrm{O}$, diaryl); 1533 $\mathrm{cm}^{-1}(\mathrm{~N}=\mathrm{N}) ; 1471 \mathrm{~cm}^{-1}\left(\mathrm{C}=\mathrm{C}\right.$, aromatic); $1324 \mathrm{~cm}^{-1}(\mathrm{C}-\mathrm{N}) ; 1103 \mathrm{~cm}^{-1}(\mathrm{C}-\mathrm{O}) ; 1031 \mathrm{~cm}^{-1}, 652$ $\mathrm{cm}^{-1}$ (for sulphonic acid); $780 \mathrm{~cm}^{-1}, 744 \mathrm{~cm}^{-1}, 586 \mathrm{~cm}^{-1}, 475 \mathrm{~cm}^{-1}$ (for substituted benzene). ${ }^{1} \mathrm{H}-\mathrm{NMR}$ : 7.2-7.4 $\delta$ (Ar-H, multiplet), $6.1 \delta$ (Ar-OH, singlet), $7.9 \delta\left(-\mathrm{SO}_{3} \mathrm{H}\right.$, singlet, $\left.1 \mathrm{H}\right)$.

\section{Determination of the percentage exhaustion and fixation}

The dye bath percentage exhaustion and fixation of the dyed fabric was determined according to the known method ${ }^{20}$ and is shown in Table 1.

Table 1. Absorption maxima $\left(\lambda_{\max }\right)$, intensities $(\log \varepsilon)$, exhaustion $(\mathrm{E})$ and fixation $(\mathrm{F})$ of acid azo dyes on wool and silk.

\begin{tabular}{ccccccc}
\hline \multirow{2}{*}{$\begin{array}{c}\text { Dyes } \\
\text { No. }\end{array}$} & \multirow{2}{*}{$\begin{array}{c}\text { Absorption maxima } \\
\lambda_{\text {max }} / \text { nm in DMF }\end{array}$} & $\begin{array}{c}\text { Intensities } \\
\log \varepsilon\end{array}$ & \multicolumn{2}{c}{$\begin{array}{c}\text { Acid azo dyeing } \\
\text { on wool }\end{array}$} & \multicolumn{2}{c}{$\begin{array}{c}\text { Acid azo dyeing } \\
\text { on silk }\end{array}$} \\
\cline { 4 - 7 } & & & $\% \mathrm{E}$ & $\% \mathrm{~F}$ & $\% \mathrm{E}$ & $\% \mathrm{~F}$ \\
\hline $\mathrm{D}_{1}$ & 465 & 4.60 & 80 & 89 & 72 & 90 \\
$\mathrm{D}_{2}$ & 445 & 4.36 & 75 & 94 & 75 & 87 \\
$\mathrm{D}_{3}$ & 450 & 4.45 & 72 & 90 & 80 & 92 \\
$\mathrm{D}_{4}$ & 435 & 4.27 & 85 & 89 & 76 & 88 \\
$\mathrm{D}_{5}$ & 430 & 4.20 & 74 & 86 & 82 & 91 \\
$\mathrm{D}_{6}$ & 420 & 4.18 & 71 & 88 & 75 & 89 \\
$\mathrm{D}_{7}$ & 422 & 4.21 & 85 & 92 & 78 & 90 \\
\hline
\end{tabular}

\section{Fastness property}

The fastness to light, sublimation and perspiration of dye pattern was assessed according to British standard: 1006-1978 and the wash fastness test according to Indian standard: IS: 765-1979. The rubbing fastness was tested by using Crock meter (Atlas) AATCC-1961, shown in Table 2 to 5.

Table 2. Results of acid azo dyeing and various fastness properties of dyes on wool.

\begin{tabular}{|c|c|c|c|c|c|c|c|c|}
\hline \multirow{2}{*}{$\begin{array}{c}\text { Dyes } \\
\text { No. }\end{array}$} & \multirow{2}{*}{$\begin{array}{c}\text { Color shades } \\
\text { on wool }\end{array}$} & \multirow{2}{*}{$\begin{array}{c}\text { Light } \\
\text { fastness }\end{array}$} & \multirow{2}{*}{$\begin{array}{l}\text { Washing } \\
\text { fastness }\end{array}$} & \multicolumn{2}{|c|}{$\begin{array}{l}\text { Perspiration } \\
\text { fastness }\end{array}$} & \multirow{2}{*}{$\begin{array}{l}\text { Sublimation } \\
\text { fastness }\end{array}$} & \multicolumn{2}{|c|}{$\begin{array}{l}\text { Rubbing } \\
\text { fastness }\end{array}$} \\
\hline & & & & Acid & Alkaline & & Dry & Wet \\
\hline $\mathrm{D}_{1}$ & Pinkish blue & 5 & 5 & 4 & 5 & 4 & 4 & 4 \\
\hline $\mathrm{D}_{2}$ & Pinkish blue & 5 & 4 & 5 & 4 & 4 & 4 & 4 \\
\hline $\mathrm{D}_{3}$ & Reddish brown & 5 & 5 & 5 & 5 & 5 & 5 & 4 \\
\hline $\mathrm{D}_{4}$ & Yellowish pink & 4 & 5 & 4 & 5 & 4 & 4 & 3 \\
\hline $\mathrm{D}_{5}$ & Chocolate brown & 4 & 4 & 5 & 5 & 4 & 5 & 4 \\
\hline $\mathrm{D}_{6}$ & Red & 5 & 5 & 5 & 5 & 5 & 4 & 3 \\
\hline $\mathrm{D}_{7}$ & Red & 5 & 4 & 5 & 5 & 4 & 5 & 4 \\
\hline
\end{tabular}


Table 3. Results of acid azo dyeing and various fastness properties of dyes on silk.

\begin{tabular}{|c|c|c|c|c|c|c|c|c|}
\hline \multirow{2}{*}{$\begin{array}{l}\text { Dyes } \\
\text { No. }\end{array}$} & \multirow{2}{*}{$\begin{array}{l}\text { Color shades } \\
\text { on silk }\end{array}$} & \multirow{2}{*}{$\begin{array}{l}\text { Light } \\
\text { fastness }\end{array}$} & \multirow{2}{*}{$\begin{array}{c}\text { Wash } \\
\text { fastness }\end{array}$} & \multicolumn{2}{|c|}{$\begin{array}{l}\text { Perspiration } \\
\text { fastness }\end{array}$} & \multirow{2}{*}{$\begin{array}{l}\text { Sublimation } \\
\text { fastness }\end{array}$} & \multicolumn{2}{|c|}{$\begin{array}{l}\text { Rubbing } \\
\text { fastness }\end{array}$} \\
\hline & & & & Acid & Alkaline & & Dry & Wet \\
\hline $\mathrm{D}_{1}$ & Pinkish blue & 5 & 4 & 4 & 5 & 5 & 4 & $3-4$ \\
\hline $\mathrm{D}_{2}$ & Pinkish blue & 5 & 4 & 5 & 4 & 4 & 4 & 3 \\
\hline $\mathrm{D}_{3}$ & Reddish brown & 4 & 4 & 4 & 5 & 5 & 4 & 4 \\
\hline $\mathrm{D}_{4}$ & Yellowish pink & 4 & 4 & 4 & 4 & 4 & 4 & $3-4$ \\
\hline $\mathrm{D}_{5}$ & Chocolate brown & 5 & 5 & 4 & 4 & 4 & 5 & 4 \\
\hline $\mathrm{D}_{6}$ & Red & 5 & 4 & 4 & 4 & 5 & 4 & 4 \\
\hline $\mathrm{D}_{7}$ & Red & 5 & 4 & 4 & 4 & 5 & 5 & $3-4$ \\
\hline
\end{tabular}

Table 4. Results of mordent acid azo dyeing and various fastness properties of dyes on wool.

\begin{tabular}{|c|c|c|c|c|c|c|c|c|}
\hline \multirow{2}{*}{$\begin{array}{c}\text { Dyes } \\
\text { No. }\end{array}$} & \multirow{2}{*}{$\begin{array}{c}\text { Color shades } \\
\text { on wool }\end{array}$} & \multirow{2}{*}{$\begin{array}{c}\text { Light } \\
\text { fastness }\end{array}$} & \multirow{2}{*}{$\begin{array}{l}\text { Washing } \\
\text { fastness }\end{array}$} & \multicolumn{2}{|c|}{$\begin{array}{l}\text { Perspiration } \\
\text { fastness }\end{array}$} & \multirow{2}{*}{$\begin{array}{l}\text { Sublimation } \\
\text { fastness }\end{array}$} & \multicolumn{2}{|c|}{$\begin{array}{l}\text { Rubbing } \\
\text { fastness }\end{array}$} \\
\hline & & & & Acid & Alkaline & & Dry & Wet \\
\hline$\overline{D_{1}}$ & Pinkish blue & 5 & 5 & 4 & 5 & 5 & 5 & 4 \\
\hline $\mathrm{D}_{2}$ & Pinkish blue & 5 & 5 & 5 & 4 & 5 & 4 & 4 \\
\hline $\mathrm{D}_{3}$ & Reddish brown & 5 & 5 & 5 & 5 & 5 & 5 & 4 \\
\hline $\mathrm{D}_{4}$ & Yellowish pink & 5 & 5 & 5 & 5 & 5 & 5 & 4 \\
\hline $\mathrm{D}_{5}$ & Chocolate brown & 5 & 4 & 5 & 5 & 4 & 5 & 4 \\
\hline $\mathrm{D}_{6}$ & Red & 5 & 5 & 5 & 5 & 5 & 4 & 4 \\
\hline $\mathrm{D}_{7}$ & Red & 5 & 5 & 5 & 5 & 5 & 5 & 4 \\
\hline
\end{tabular}

Table 5. Results of mordent acid azo dyeing and various fastness properties of dyes on silk.

\begin{tabular}{|c|c|c|c|c|c|c|c|c|}
\hline \multirow{2}{*}{$\begin{array}{l}\text { Dyes } \\
\text { No. }\end{array}$} & \multirow{2}{*}{$\begin{array}{l}\text { Color shades } \\
\text { on silk }\end{array}$} & \multirow{2}{*}{$\begin{array}{l}\text { Light } \\
\text { fastness }\end{array}$} & \multirow{2}{*}{$\begin{array}{c}\text { Wash } \\
\text { fastness }\end{array}$} & \multicolumn{2}{|c|}{ Perspiration } & \multirow{2}{*}{$\begin{array}{l}\text { Sublimation } \\
\text { fastness }\end{array}$} & \multicolumn{2}{|c|}{ Rubbing } \\
\hline & & & & Acid & Alkaline & & Dry & Wet \\
\hline $\mathrm{D}_{1}$ & Pinkish blue & 5 & 5 & 4 & 5 & 5 & 5 & 4 \\
\hline $\mathrm{D}_{2}$ & Pinkish blue & 5 & 5 & 5 & 4 & 5 & 4 & 4 \\
\hline $\mathrm{D}_{3}$ & Reddish brown & 5 & 5 & 5 & 5 & 5 & 5 & 4 \\
\hline $\mathrm{D}_{4}$ & Yellowish pink & 5 & 5 & 5 & 5 & 5 & 5 & 4 \\
\hline $\mathrm{D}_{5}$ & Chocolate brown & 5 & 4 & 5 & 5 & 4 & 5 & 4 \\
\hline $\mathrm{D}_{6}$ & Red & 5 & 5 & 5 & 5 & 5 & 4 & 4 \\
\hline $\mathrm{D}_{7}$ & Red & 5 & 5 & 5 & 5 & 5 & 5 & 4 \\
\hline
\end{tabular}

\section{Results and discussion}

\section{Physical properties of dyes}

All the dyes are obtained as crystal powder ranging from yellowish pink to pinkish blue in colours. The purity of the dyes were checked by TLC using methanol-water-acetic acid (12:3:7) solvent system. The TLC results show that only single spot observed for each dye. The purified dyes have melting point measured by open capillary tube. The melting points were uncorrected. 
The results of elemental analysis content of each dyes are consistent with the predicted structure as shown in Scheme 1. The number of azo group is almost one for each dye. The nitrogen content and number of azo group for each dye are co-related with each other. The IR spectrum of each dye comprises the important features of aromatic, azo, hydroxyl and keto groups. The ${ }^{1} \mathrm{H}$ NMR spectra of all the diazo compounds based on 2,4dihydroxybenzophenone shows an important signals at their respective positions confirmed the structures of various dyes as shown in Scheme 1.

The visible absorption spectroscopic properties of dyes were recorded in double distilled water. The absorption maxima ( $\lambda_{\max }$ ) of all the dyes fall into the range of $422-465 \mathrm{~nm}$ in water, as shown in Table 1. The value of the logarithm of molar extinction coefficient $(\log \varepsilon)$ of all the dyes were in the range of $4.21-4.60$, consistent with their high intensity of absorption.

Moreover, the presence of electron donating or electron attracting groups did not bring about any marked increase or decreased in $\lambda_{\max }$ in the visible region and that $\log \varepsilon$ remained nearly constant. However, electron attracting substituents like $-\mathrm{SO}_{3} \mathrm{H}$ and $-\mathrm{COOH}$ in the substituent group of the coupler increase polarizability, and will results in bathochromic shifts. This leads to decrease in energy between the highest occupied molecular orbital and lowest unoccupied molecular orbital and thus $\pi \rightarrow \pi^{*}$ electronic transition takes place at lower frequency photon, resulting in the bathochromic shift of the visible absorption band.

\section{Dyeing properties of dyes}

The acid azo dyes were applied at $2 \%$ depth on wool and silk fabric respectively. Their dyeing properties are given in Table 2 to Table 5 . These dyes gave a wide range of colours varying from yellowish pink to pinkish blue shades with good levelness, brightness and depth on the fabrics. The variation in the shades of the dye fabric results from both the nature and position of the substituent present on the diazotized compound. The dyeing showed an excellent fastness to light, with very good to excellent fastness to washing, perspiration and sublimation, however it shows poor rubbing fastness.

A remarkable degree of levelness after washing is observed. This may be attributed to good penetration and affinity of the dye molecule in to fiber structure. The most prominent features of these dyes is that, the dye patterns treated with $\mathrm{Cr}$ (III) salt solution afford excellent shining shade of dyes. This might be due to the chrome complex formation on fiber matrix. The bacterial activities of chrome complexes of dyes were monitored against the plant pathogens. The results show that these dyes are inhibiting the bacteria about 70 to $80 \%$ and are shown in Table 6 . The dye pattern of chrome treated dye may be affordable for human body.

Table 6. Antibacterial activity of acid azo chrome dyes $\left(D_{1}-D_{7}\right)$.

\begin{tabular}{ccccc}
\hline Dyes & \multicolumn{4}{c}{ Organism } \\
\cline { 2 - 5 } No. & E. coli & S. aureus & S. typhi & B. subtilis \\
\hline $\mathrm{D}_{1}$ & +++ & ++ & ++ & ++ \\
$\mathrm{D}_{2}$ & + & + & + & + \\
$\mathrm{D}_{3}$ & +++ & ++ & ++ & ++ \\
$\mathrm{D}_{4}$ & + & + & + & + \\
$\mathrm{D}_{5}$ & + & + & + & + \\
$\mathrm{D}_{6}$ & ++ & ++ & + & ++ \\
$\mathrm{D}_{7}$ & +++ & +++ & ++ & ++ \\
\hline
\end{tabular}

(Diameter of inhibition zone in $\mathrm{mm}$; concentration $100 \mu \mathrm{g} / \mathrm{mL}$ )

$(-)=$ inactive $(10 \mathrm{~mm}$ and less $) ;(+)=$ weakly active $(11-15 \mathrm{~mm})$;

$(++)=$ moderately active $(16-20 \mathrm{~mm}) ;(+++)=$ highly active $(21 \mathrm{~mm}$ and above $)$. 


\section{Conclusions}

Produced acid azo dyes have good fastness to light, sublimation and perspiration but show poor rubbing fastness properties. The nature of the substituent in the coupling components has a little influence on the visible absorption and shade of the dyeing. Comparison of above two dyes reveals that mordent acid azo dyes have better shades than acid azo dyes.

\section{Acknowledgment}

The authors are thankful to the principal, Dr. D. J. Desai and C.V.M. for providing necessary research facilities. Authors are also thankful to Mr. Ashok C. Kapadia, Mr. Pradeep N. Mistry of Color Tax (Pvt) Ltd., Surat for characterization of azo group and giving the standard of fastness properties and Raju Mehta of G.P.C.B., Surat for providing useful chemicals.

\section{References}

1. Cumming W M and Howie G, J Chem Soc., 1933, 133.

2. Peters A T and Walker D, J Chem Soc., 1956, 429.

3. Vogel A I, A Textbook of Practical Organic Chemistry, $3^{\text {rd }}$ Ed., Longman: London, 1961, 620.

4. Gordon P F and Gregory P, Organic Chemistry in Colour, $1^{\text {st }}$ Ed., Springer-Verlag Berlin Heidelberg: New York, 1983, 60.

5. Mohamed S K, Nour A M and El-Din, J Chem Res.,(s) 1999, 8, 508.

6. Naik R D, Desai C K and Desai K R, Oriental J Chem., 2000, 16, 159.

7. Yurteri S, Onen and Yagci Y, Euro Polym J, 2002, 38(9), 1845.

8. Huang W and Hou B, Tribology Letters, Springer US, 2004, 18(4), 445.

9. Huang, Lu X, Springer Berlin Heidelberg, New York, 2005, 56(2), 171.

10. Johnson M and Hauserman R G, J Appl Polym Sci., 1977, 21, 3457.

11. Kamogawa H and Nanasawa M, Yukio Uehara, 1977, 15, 675.

12. Allmer K, Hult and Ranby B, J Polym Sci., 1989, 27, 3419.

13. Frantisek V, Hana N, Czech. 176, 377 1979. (CA 91:P58685x)

14. Raouf B, American Colour \& Chemical Corp. US pat., 4, 066, 388, 1978. (CA 88:P106751c)

15. Brian B and Donald C, Sandoz- pat. G.M.B.H. DE 3, 417, 782 1984. (CA 102: P133487k)

16. Markus R T and Jakob K, Ciba-Geiga A-G. Eur Pat. Appl. EP, 169, 808, 1986. (CA 104:P216418f)

17. Dixit B C, Patel H M and Desai D J, J Serb Chem Soc., 2007, 72, 119.

18. Frirz-David H E and Blengy L, Fandamental process of Dye Chemistry, $3^{\text {rd }}$.Ed, Willy: New York, 1949, 241.

19. Szymczyk M, Shafei A E and Freeman H S, Dyes and Pigments, 2007, 72, 8.

20. Shishtawy R M E, Youssef Y A, Ahmed N S E and Mousa A A, Dyes and Pigments 2007, 72, 57. 


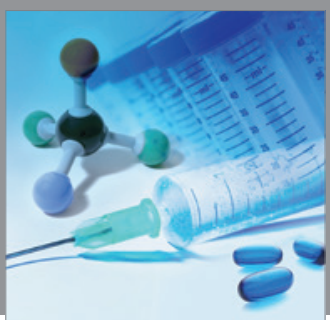

International Journal of

Medicinal Chemistry

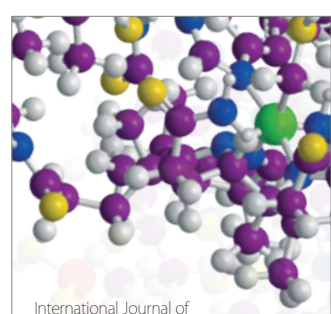

Carbohydrate Chemistry

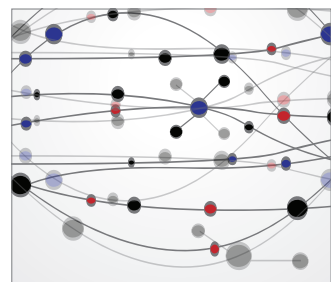

The Scientific World Journal

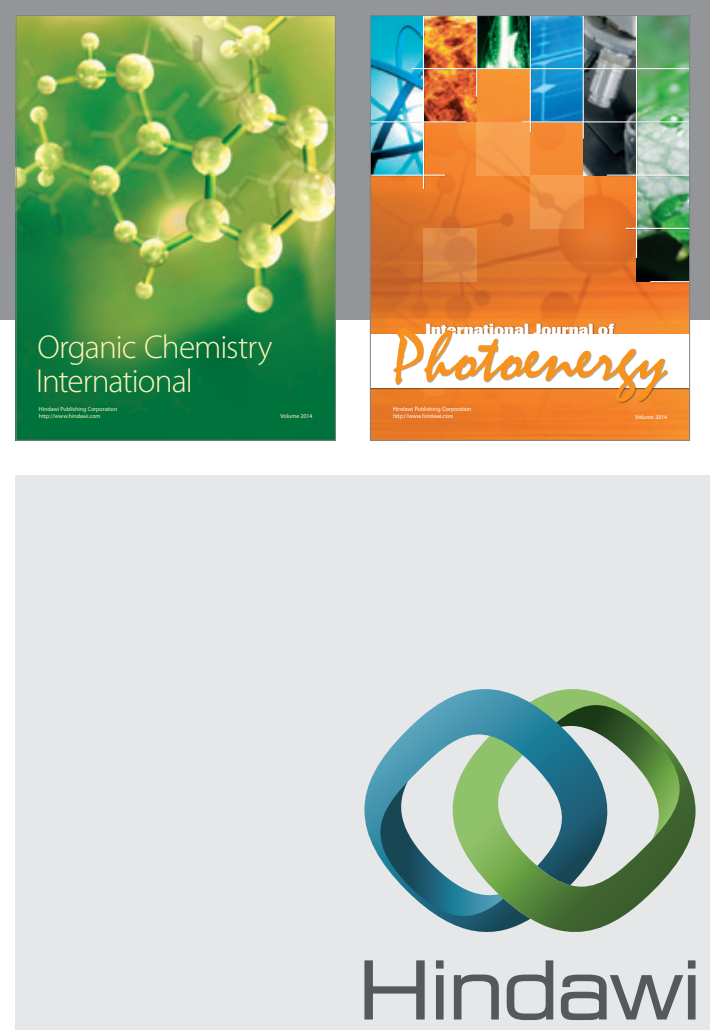

Submit your manuscripts at

http://www.hindawi.com
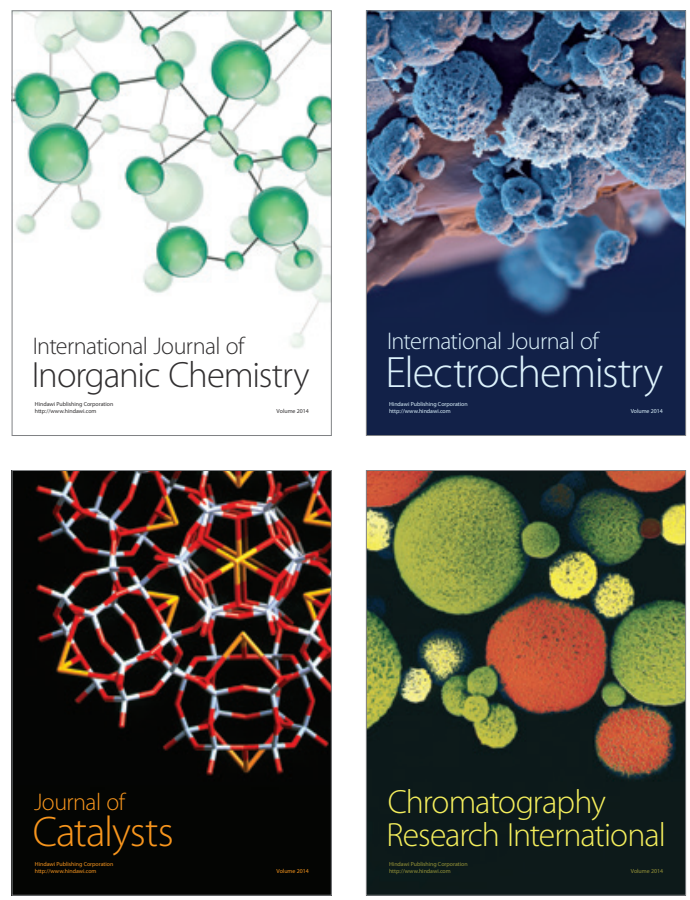
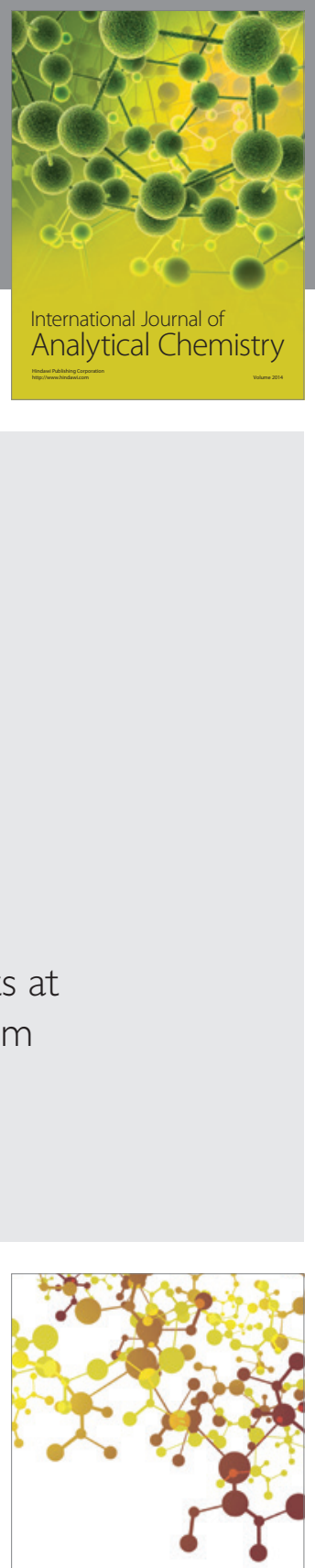

Journal of

Applied Chemistry
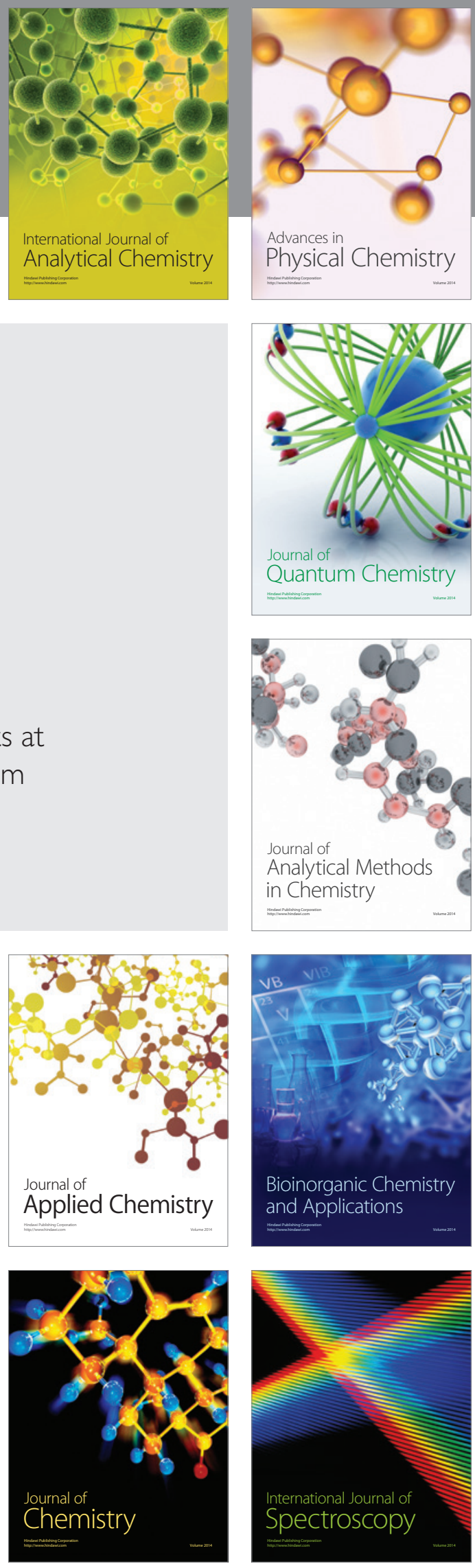